\title{
Aerometabolická náročnost vytrvalostního běhu u mužů při došlapu na přední část nohy a při došlapu na zadní část nohy
}

\section{Aerometabolic economy of long distance run using the forefoot and rearfoot style}

\author{
Vladimír Pospíchal, Jan Novotný
}

Fakulta sportovních studií Masarykovy univerzity, Brno

\begin{abstract}
Abstrakt
Článek se zabývá problematikou optimálniho běžeckého kroku u vytrvalostních běžců amatérů. Běžecký krok by měl být energeticky co nejméně náročný, tedy ekonomický. Cílem studie je zjistit, zda běh přes predni část nohy je více ekonomický než běh přes zadní část nohy.

Testování se zúčastnilo 15 běžcu․ Měrení probihalo v laboratornich podmínkách na běhátku. Rychlost, kterou testované osoby běžely, byla $12 \mathrm{~km} \cdot \mathrm{h}^{-1}$. Při vyhodnocování jsme se zaměřili na ukazatele ekonomiky běhu - minutový př́jem kyslíku, minutový př́jem kyslíku v prepočtu na kilogram hmotnosti a srdeční frekvenci. Cílem studie je přispět ke zjištění, zda je u vytrvalostního běhu energeticky náročnějšsi běh s došlapem na zadní část nohy nebo běh s došlapem na prední část nohy. V tomto článku jsme se zaměrili na dva významné faktory ovlivňující ekonomiku běhu - minutový př́jem kysliku a minutový př́jem kysliku v přepočtu na kilogram hmotnosti.

Statisticky významný rozdíl $(p<0,05)$ při běhu s došlapem na přední část nohy a na zadní část nohy byl u minutového př́jmu kysliku. Při běhu s došlapem na zadní část nohy byla průměrná hodnota minutového př́imu kyslíku o 0,114 l. $\mathrm{min}^{-1}$ nižší.

Mohli bychom usuzovat, že běh s došlapem na zadni část nohy je ekonomicky výhodnější, než běh s došlapem na prední část nohy. Z naměrených 15 běžcư nemüžeme jednoznačně řici, zda běh s došlapem na zadni část nohy je ekonomicky výhodnějǔsí, než běh s došlapem na prední část nohy.
\end{abstract}

\section{Abstract}

The research project focuses on the problem of the optimum cross step in long distance run. Step should be energetically most favourable-economics. We want to answer the question whether and under what conditions it is energetically preferable to endurance runner's pace with the impact on the forefoot or rearfoot.

Testing subjects were 15 athletes. Athletes held running pace $12 \mathrm{~km} \cdot \mathrm{h}^{-1}$. When we evaluated results, we focused on indicators running economy - minute oxygen uptake, minute oxygen uptake per kilogram of weight and heart rate. The aim of the study is to contribute to determine whether there is a more energy-intensive endurance running with an impact on the rearfoot or the impact on the forefoot. In this article, we focus on two important factors affecting running economy - minute oxygen uptake and minute oxygen uptake per kilogram of weight.

Statistically significant difference $(p<0.05)$ the forefoot and rearfoot was in oxygen uptake. The average value rearfoot of minute oxygen uptake of $0.114 \mathrm{l} \cdot \mathrm{min}^{-1}$ is below than forefoot. We conclude that rearfoot is more economical than forefoot. From the measured 15 runners, we cannot clearly say whether running rearfoot or forefoot is more economical.

Klíčová slova: Ekonomika běhu, běžecký krok, vytrvalostní běh, běh přes špičku, běh přes patu, aerometabolické ukazatele, minutový př̉jem kyslíku, srdeční frekvence

Key words: Running economy, cross step, long distance run, toe run, heel run, cardio-respiratory indicators, minute oxygen uptake, heart rate 


\section{ÚVOD}

Ekonomiku běhu definujeme jako poptávku po energii pro určitou rychlost běhu. Je určena měřením ve steady state - minutového př́ijmu kyslíku a respirační výměny RER. V úvahu přichází i tělesná stavba běžce. Běžci s dobrou ekonomikou běhu spotřebují méně energie. Mají i menší spotřebu kyslíku než běžci s horší ekonomikou běhu při stejné rychlosti běhu (Saunders et al., 2004). Existuje silný vztah mezi ekonomikou běhu a výkonem při běhu na delší vzdálenosti. U profesionálních vytrvalců s podobným mají běžci s dobrou ekonomikou běhu vyšší př́edpoklad dosáhnout lepší výkonnosti než běžci s vysokou hodnotou (Saunders et al., 2004). Vysoká ekonomika běhu může být také důležitá při udržení stálosti vnitřního prostředí v organizmu, zamezení přehřívání organizmu a může tak přispět k vyšší výkonnosti (Noakes, 2004).

Noakes ve své publikaci Lore of running uvádí studii Conleyho a Krahenbuhla z roku 1980. Byla pozorována skupina 12 špičkových atletů, jejichž osobní rekordy na $10 \mathrm{~km}$ byly mezi 30:31 až 33:33 minut. Jejich hodnota se pohybovala od $67 \mathrm{do} 78 \mathrm{ml} \cdot \mathrm{kg}^{-1} \cdot \mathrm{min}^{-1}$. Samotná vysoká hodnota $\mathrm{V}_{2}{ }_{2} \max$ nepředurčovala dobrý čas v běhu na $10 \mathrm{~km}$. Našel se ovšem vztah mezi minutovým př́ijmem kyslíku a submaximální zátěží, potažmo ekonomikou běhu. U těchto špičkových atletů se našla určitá souvislost minutového př́ijmu kyslíku a ekonomiky běhu při rychlostech běhu 14,$5 ; 16,1$ a $17,7 \mathrm{~km} \cdot \mathrm{h}^{-1}$. Tedy běžci s nejnižším minutovým př́ijmem kyslíku při uvedených rychlostech běhu měli také nejlepší ekonomiku běhu a zároveň nejlepší čas na $10 \mathrm{~km}$. Autoři došli k závěru, že vysoká hodnota $\dot{V}_{2} \max \left(\right.$ nad $\left.67 \mathrm{ml} \cdot \mathrm{kg}^{-1} \cdot \mathrm{min}^{-1}\right)$ může pomoci $\mathrm{k}$ lepší výkonnosti. Nicméně u této skupiny běžců byla ekonomika běhu a ne $\mathrm{km} \cdot \mathrm{h}^{-1}$ faktorem $\mathrm{k}$ dosažení vyšší výkonnosti v běhu na $10 \mathrm{~km}$ (Noakes, 1988).

Interpretace vysoké hodnoty $\dot{V}_{2} \max$ je, že vyšší rychlost běhu potřebuje také vysoký minutový př́ijem kyslíku. Individuální hodnota $\mathrm{V}_{2} \max$, kterou dosáhne sportovec při testu v laboratoři nebo $\mathrm{v}$ terénu, bude určující pro jeho ekonomiku běhu. Při stejné rychlosti běhu budou mít běžci se špatnou ekonomikou běhu vyšší spotřebu kyslíku než běžci s vynikající ekonomikou běhu (Noakes, 1988).

Ekonomika běhu se měří v laboratorních podmínkách při běhu na běhátku. Ačkoliv to není stejné, jako když běžíme po zemi venku nebo v prírodě, dává nám to dobrou indikaci, jaká je ekonomika běhu a jak se ekonomika běhu mění v čase. Pro zjištění, zda jsou změny v ekonomice běhu skutečné či nikoliv, důkladně vybíráme čas testu, po který běžci běží, a jejich obuv (Saunders et al., 2004).

Ekonomika běhu je stálý test, který zjistí i relativně malé změny vyvolané tréninkem nebo dalším působením. Intervence ke zlepšení ekonomiky běhu jsou stále vyhledávané nejen samotnými běžci, ale i jejich trenéry, kouči a sportovními vědci. Trénink ve vysoké nadmořské výšce a silový trénink jsou dvě tréninkové metody, jak dosáhnout lepší ekonomiku běhu. Silový trénink stimuluje svaly k utilizaci větší energie a redukuje množství zbytečné energie v brzdných silách. Nadmořská výška zvyšuje metabolické aspekty kosterních svalů, které usnadňují efektivnější využití kyslíku (Saunders et al., 2004).

Biomechanickou analýzu sil působících na podrážku u běžců při dopadu na patní a střední část nohy publikovali Cavanagh a Lafortune (1980). Průběh sil v čase, které působí na chodidlo člověka při běhu „pata-špička“, popsali např. Robbert et al. (1992). Anderson (1996) se věnoval především biomechanickým faktorům ovlivňujícím ekonomiku běhu. Kyröläinen et al. (2001) porovnávali ekonomiku běhu při jeho různých rychlostech: Př́ijem kyslíku roste s rychlostí běhu přibližně lineárně. Nicméně jsou určité odlišnosti. Zatsiorsky (2002) podal komplexní pohled na působení sil podložky na chodidlo člověka při různých pohybových činnostech, včetně chůze a běhu. Hoffman (2002) ve své publikaci popisuje energetickou ekonomiku při různých pohybových aktivitách člověka. Při běhu ji reprezentuje př́jem kyslíku při určité rychlosti. S narůstající rychlostí se př́jem kyslíku zvyšuje. Ekonomiku běhu silně ovlivňuje délka kroku. Noakes (2003) ve své publikaci shrnul faktory, které ovlivňují ekonomiku běhu: běh do kopce, s kopce a po rovině, zásoby energie ve svalech, biomechanické faktory, typ tréninku, tělesná zdatnost, věk, únava, pohlaví, váha, oblečení, obuv, povětrnostní podmínky. Ästrand et al. (2003) se zmiňují o dalších faktorech, např. použití štítu proti větru, a také o energetické náročnosti chůze, joggingu a běhu, která je vyjádřena v joulech nebo kaloriích. Numella (2007) došel k závěru, že ekonomicky výhodnější je běh, při němž je kratší doba kontaktu nohy s podložkou.

V současné době se stále považuje za dobrý ukazatel ekonomiky běhu minutový př́jem kyslíku v přepočtu na hmotnost člověka $\left(\mathrm{VO}_{2} \cdot \mathrm{kg}^{-1}\right)$ a rychlost běhu (Saunders et al., 2004). Za ekonomicky výhodnější se považuje běh, který je spojen s nižším $\mathrm{VO}_{2} \cdot \mathrm{kg}^{-1}$ a rychlostí běhu (Jones, 2007). V studii Chen et al. z roku 2009 se také píše o parametrech, které determinují ekonomiku běhu. Chen et al. mluví o minutovém př́ijmu kyslíku, minutové ventilaci, respirační výměně a srdeční frekvenci. 
Gruber et al. (2013) se zabývá ekonomikou běhu a mírou sacharidů při došlapu na přední a zadní část nohy. Gruber et al. se rozhodli provést rozsáhlejší studii s využitím obvyklých technik došlapu - s došlapem na přední část nohy a s došlapem na zadní část nohy. Cílem jejich studie bylo zjistit, zda byly rozdíly v ekonomice běhu mezi skupinami a zda ekonomika běhu byla rozdílná, když běželi odlišným způsobem běhu. Porovnávali 19 běžců, kteří obvykle dopadají na zadní část nohy, a 18 běžců, kteří dopadají na přední část nohy. Měření probíhalo na běhátku při rychlostech 3,0;3,5 a $4 \mathrm{~m} \cdot \mathrm{s}^{-1}$, což odpovídá rychlosti běhu 10,8; 12,6 a $14,4 \mathrm{~km} \cdot \mathrm{h}^{-1}$. Nebyly zjištěny rozdíly u minutového př́ijmu kyslíku mezi skupinami, když běželi obvyklým způsobem běhu. Výsledky naznačují, že běh s došlapem na přední část nohy není ekonomicky výhodnější než běh s došlapem na zadní část nohy (Gruber et al., 2013).

Cílem studie je přispět ke zjištění, zda je u vytrvalostního běhu energeticky náročnější běh s došlapem na zadní část nohy nebo s došlapem na přední část nohy. V tomto článku jsme se zaměřili na dva významné faktory ovlivňující ekonomiku běhu - minutový příjem kyslíku a minutový př́ijem kyslíku v přepočtu na kilogram hmotnosti.

\section{METODIKA}

Způsob řešení projektu spočívá v provedení experimentální srovnávací studie u mužů. Porovnávány byly hodnoty ukazatelů ekonomiky běhu při dvou různých způsobech běhu. Běh s došlapem na přední část nohy a běh s došlapem na zadní část nohy.

Testování se zúčastnili jen muži ve věku 20-40 let, pro které je běh součástí volného času. Běh je pro ně jedním ze základních způsobů, jak aktivně trávit volný čas po práci či škole. V této studii bylo vybráno náhodným výběrem 15 mužů. Kritériem výběru byla testovací rychlost, kterou museli udržet po celou dobu konání testu, a věk probandů.

Abychom zajistili objektivnost běžeckého způsobu, zvolili jsme následující postup: první testovaná osoba začínala první test $\mathrm{s}$ došlapem na přední část nohy a druhý test $\mathrm{s}$ došlapem na zadní část nohy. Druhá osoba začínala první test s došlapem na zadní část nohy a druhý test s došlapem na přední část nohy. Tím jsme vyrušili negativní dopady, které by mohly ovlivnit výsledky, kdybychom všechny testy začínali s došlapem na přední část nohy.

Pro vyhodnocení naměřených hodnot ekonomiky běhu jsme použili př́istroj MetaLyzer 3B-R2, software Microsoft Excel 2010 a STATISTICA 10. Pro zajištění validity běžeckého kroku jsme testované osoby natáčeli na kameru a vizuálně pozorovali, popř́ípadě jim běžeckou techniku opravovali během testu.

Pro vyhodnocení jsme použili úsek běhu mezi 7.-12. minutou, kdy u testovaných osob již bylo dosaženo steady state. Zaměřili jsme se na minutový př́jem kyslíku v přepočtu na kilogram hmotnosti, minutový př́jem kyslíku, srdeční frekvenci.

Test probíhal v laboratorních podmínkách na běhátku. Testovací rychlost byla $12 \mathrm{~km} \cdot \mathrm{h}^{-1}$, tedy běžecké tempo odpovídající $5 \mathrm{~min} \cdot \mathrm{km}^{-1}$, bez zvyšování rychlosti a při nulovém sklonu běhátka. Rychlost $12 \mathrm{~km} \cdot \mathrm{h}^{-1}$ byla zvolena záměrně, aby testované osoby dosáhly steady state. Testované osoby se po celou dobu testu pohybovaly $\mathrm{v}$ aerobním režimu.

Testované osoby běžely rychlostí $12 \mathrm{~km} \cdot \mathrm{h}^{-1}$ po dobu 12 minut. Testované osoby absolvovaly 2 testy. Oba testy absolvovaly v jeden den. Pauza mezi jednotlivými testy byla vždy minimálně 30 minut, aby došlo k dostatečné regeneraci po předchozím testu. Vzhledem $\mathrm{k}$ tomu, že se testované osoby po celou dobu testu pohybovaly v pásmu steady state - pod ANP, nebylo nutné rozdělit testování do více dnů.

Testování se zúčastnilo 15 mužů. Průměrný věk testovaných byl 25,20 $\pm 2,90$ let. Tělesná výška byla průměrně $180,46 \pm 5,87 \mathrm{~cm}$. Průměrná váha byla 74,33 \pm 7,61 kg. A průměr BMI byl 22,73 $\pm 1,75$.

\section{Aerometabolické ukazatele ekonomiky běhu:}

-Minutový př́iem kyslíku - $\mathrm{VO}_{2}\left(1 \cdot \mathrm{min}^{-1}\right)$

-Minutový př́jem kyslíku v přepočtu na kilogram hmotnosti $-\dot{V}_{2} \cdot \mathrm{kg}^{-1}\left(\mathrm{ml} \cdot \mathrm{kg}^{-1} \cdot \mathrm{min}^{-1}\right)$ 


\section{VÝSLEDKY}

Minutový př́ijem kyslíku - ${ }^{\prime} O_{2}$

Při běhu s došlapem na přední část nohy byl průměr $V_{2} \mathrm{O}_{2} 3,208 \pm 0,381 \cdot \mathrm{min}^{-1}$. Při běhu s došlapem na zadní část nohy byl průměr 3,094 $\pm 0,361 \cdot \mathrm{min}^{-1}$ (Obr. 1). Statistická významnost rozdílu minutového př́jmu kyslíku při běhu $\mathrm{s}$ došlapem na přední část nohy a s došlapem na zadní část nohy byla $\mathrm{p}=0,030909$ (Tab. 1). Tento výsledek je statisticky významný

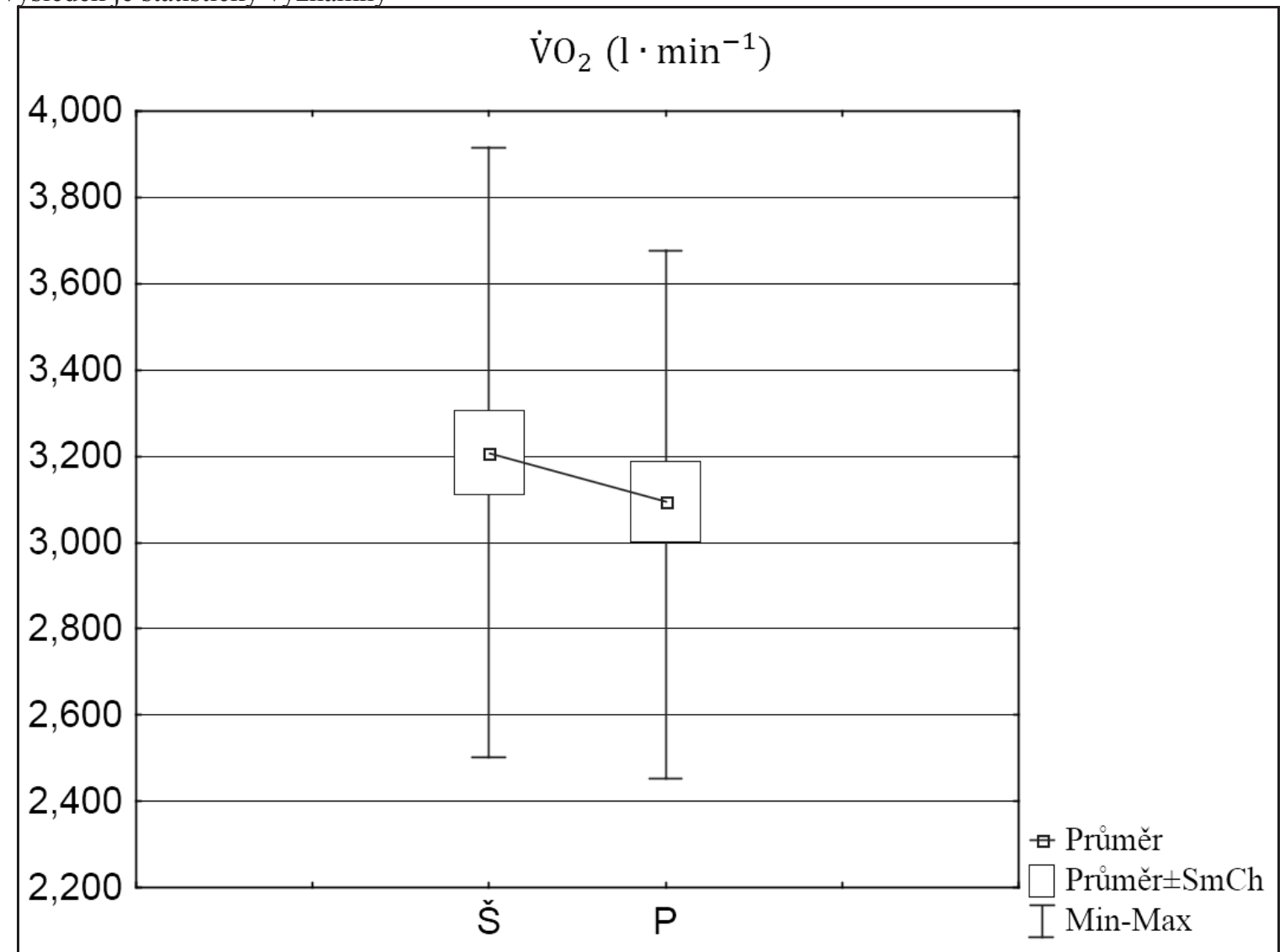

Obr. 1: Krabicový graf $\mathrm{V}_{2}$

Legenda: $\mathrm{VO}_{2}$ - minutový př́ijem kyslíku, $\breve{\mathrm{S}}$ - běh s došlapem na přední část nohy, $\mathrm{P}$ - běh s došlapem na zadní část nohy

Minutový příjem kyslíku v přepočtu na kilogram hmotnosti - $V^{\prime} \mathrm{O}_{2} \cdot \mathrm{kg}^{-1}$

Při technice běhu s došlapem na přední část nohy byl naměřen průměr V́O $\mathrm{O}_{2} \cdot \mathrm{kg}^{-1} 44,0 \pm 3,59 \mathrm{ml} \cdot \mathrm{kg}^{-1} \cdot \mathrm{min}^{-1}$. Při běhu s došlapem na zadní část nohy byl průměr $42,8 \pm 4,19 \mathrm{ml} \cdot \mathrm{kg}^{-1} \cdot \mathrm{min}^{-1}$. (Obr. 2). Statistická významnost rozdílu $\mathrm{V}_{2} \cdot \mathrm{kg}^{-1}$ při běhu s došlapem na přední část nohy a s došlapem na zadní část nohy byla $\mathrm{p}=0,088403$

(Tab. 1). Nejde tedy o statisticky významný výsledek 


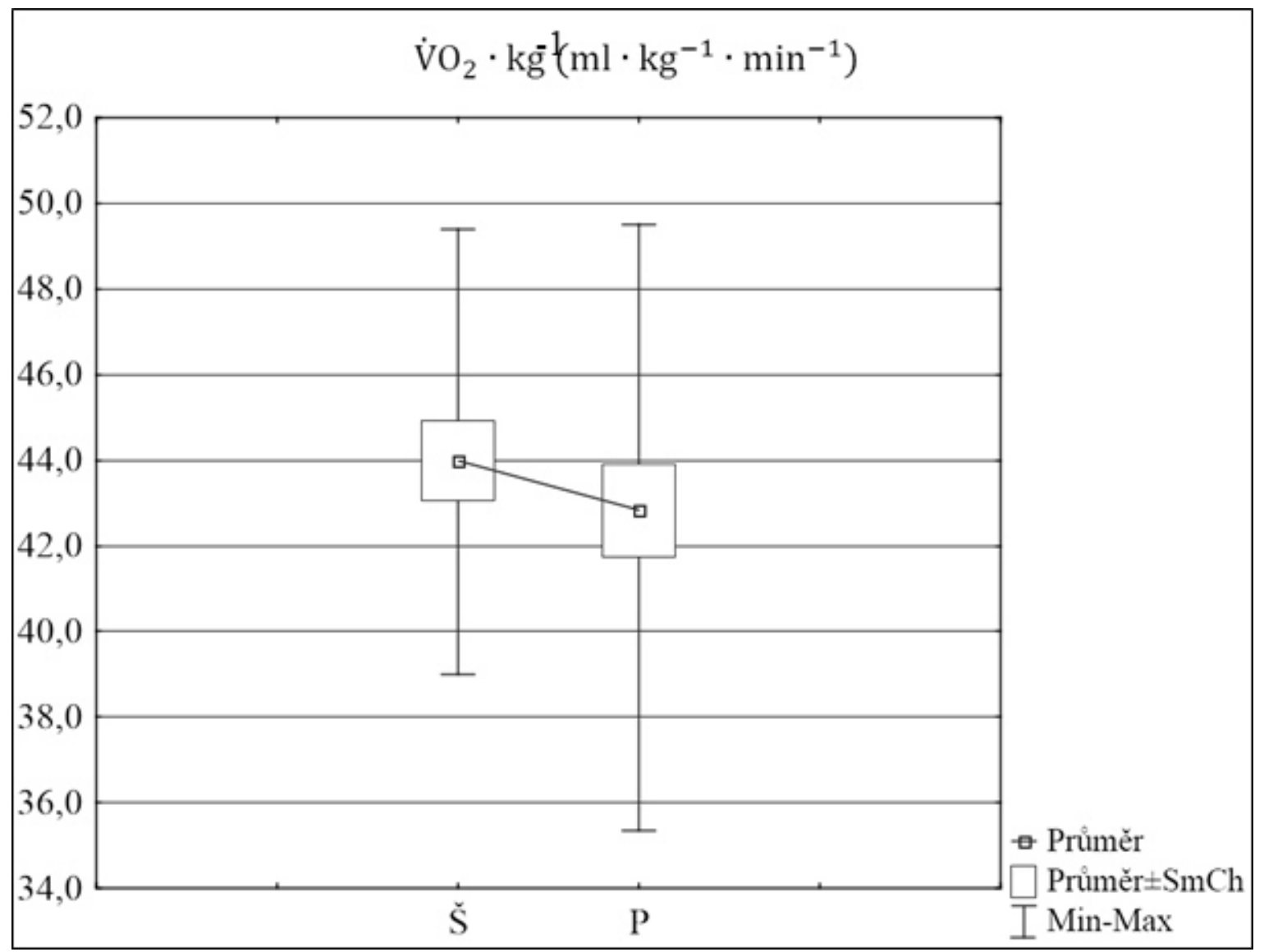

Obr. 2: Krabicový grafVO $\cdot \mathrm{kg}^{-1}$

Legenda: $\mathrm{VO}_{2} \cdot \mathrm{kg}^{-1}$ - minutový prŕijem kyslíku v přepočtu na kilogram hmotnosti, $\mathrm{S}$ - běh s došlapem na přední část nohy, $\mathrm{P}$ - běh s došlapem na zadní část nohy

Tab. 1: Výsledky testu - kardiorespirační ukazatele při dopadu na špičku a patu

\begin{tabular}{|c|c|c|c|c|c|}
\hline & & & $\mathbf{n}$ & $\mathbf{Z}$ & $\mathbf{p}$ \\
\hline \multirow{2}{*}{$\dot{\mathrm{VO}}_{2}\left(1 \cdot \min ^{-1}\right)$} & průměr - špička & 3,208 & \multirow{2}{*}{15} & \multirow{2}{*}{2,158255} & \multirow{2}{*}{0,030909} \\
\hline & průměr - pata & 3,094 & & & \\
\hline \multirow{2}{*}{$\begin{array}{l}\mathrm{VO}_{2} \times \mathrm{kg}^{-1} \\
\left(\mathrm{ml} \cdot \mathrm{kg}^{-1} \cdot \min ^{-1}\right)\end{array}$} & průměr - špička & 44,0 & \multirow{2}{*}{15} & \multirow{2}{*}{1,703886} & \multirow{2}{*}{0,088403} \\
\hline & průměr - pata & 42,8 & & & \\
\hline \multirow{2}{*}{$\begin{array}{c}\mathrm{SF} \\
\left(\text { tep } \cdot \min ^{-1}\right)\end{array}$} & průměr - špička & 168,2 & \multirow{2}{*}{15} & \multirow{2}{*}{0,170389} & \multirow{2}{*}{0,864705} \\
\hline & průměr - pata & 167,7 & & & \\
\hline
\end{tabular}

Legenda: $\mathrm{V} \mathrm{O}_{2} \cdot \mathrm{kg}^{-1}-$ minutový př́jem kyslíku $\mathrm{v}$ přepočtu na kilogram hmotnosti, $\mathrm{V} \mathrm{O}_{2}-$ minutový př́jem kyslíku, SF - srdeční frekvence, n- počet platných, Z - testová statistika, p - statistická významnost

\section{DISKUSE}

Při vytváření hypotéz jsme vycházeli jednak z rešerší, ale také z vlastní praxe. Za ideální techniku běhu považujeme běh s došlapem na přední část nohy. Sledovali jsme ukazatele ekonomiky běhu: minutový př́ijem kyslíku - $\mathrm{VO}_{2}$, minutový př́jem kyslíku v přepočtu na kilogram hmotnosti - $\mathrm{VO}_{2} \cdot \mathrm{kg}^{-1}$, srdeční frekvenci - SF.

Průměr minutového př́ijmu kyslíku při běhu s došlapem na zadní část nohy byl 3,094 $1 \cdot \mathrm{min}^{-1}$. Byl zjištěn určitý vztah mezi minutovým př́jmem kyslíku a ekonomikou běhu. Tento jev byl zjištěn u špičkových běžců. 
Rychlost, při které byli běžci testováni, byla vyšší než při našem testování (Noakes, 1988). V pilotní studii jsme nastavili testovací rychlost běhu na $14 \mathrm{~km} \cdot \mathrm{h}^{-1}$. Tato rychlost se nejvíce blížila minimální rychlosti běhu, př́i které byly zjištěny rozdíly v ekonomice běhu u měření Conleyho a Krahenbuhla (1980). Rychlost, při které byly pozorovány změny v ekonomice běhu, byla 14,$5 ; 16,1 \mathrm{a} 17,7 \mathrm{~km} \cdot \mathrm{h}^{-1}$. Rychlost $14 \mathrm{~km} \cdot \mathrm{h}^{-1} \mathrm{se} \mathrm{v}$ našich podmínkách neosvědčila. Běžci se při běhu blížili a někteří se dostali i nad anaerobní práh. My jsme potřebovali, aby se testované osoby po většinu času pohybovaly pod anaerobním prahem a dosáhly rovnovážného stavu. Hodnoty srdeční frekvence a minutového př́ijmu kyslíku se při konstantní rychlosti výrazně nezvyšují.

Neméně důležitým ukazatelem ekonomiky běhu je minutový př́ijem kyslíku v přepočtu na kilogram hmotnosti. U minutového př́ijmu kyslíku v přepočtu na kilogram hmotnosti byl rozdíl mezi během přes přední část nohy a během s došlapem na zadní část nohy $1,2 \mathrm{ml} \cdot \mathrm{kg}^{-1}$. Ekonomicky méně výhodný byl v tomto př́padě opět běh s došlapem na přední část nohy $44,0 \mathrm{ml} \cdot \mathrm{kg}^{-1} \cdot \mathrm{min}^{-1}$. Průměrná hodnota při běhu s došlapem na zadní část nohy byla $42,8 \mathrm{ml} \cdot \mathrm{kg}^{-1} \cdot \mathrm{min}^{-1}$. V tomto př́padě se nejedná o statisticky významný rozdíl při běhu s dopadem na přední část nohy a na zadní část nohy (tab. 1). Průměrné hodnoty srdeční frekvence nevykazují velké rozdíly ve výsledcích při běhu přes špičku nebo při běhu přes patu.

Testování se zúčastnilo 15 běžců. Z toho jen tři osoby vykazovaly výsledky, které jsme před začátkem měření očekávali: Že běh s došlapem na přední část nohy je energeticky méně náročný a zároveň by měl být $\mathrm{i}$ rychlejší. Pokud se podíváme na každého běžce zvlášs' (Obr. 3), tak z většiny námi naměřených hodnot vyplývá, že vyšší hodnoty $\mathrm{V}_{2} \mathrm{O}_{2} \cdot \mathrm{kg}^{-1}$ jsou při běhu přes přední část chodidla. Až na tři testované osoby jsou všechny naměřené hodnoty běhu přes zadní část nohy nižší, tedy ekonomičtější, než při běhu přes přední část nohy. Jsou ale tyto rozdíly v ekonomice běhu tak zásadní, že dokážou výrazně zlepšit čas běhu na $10 \mathrm{~km}$ nebo maraton?

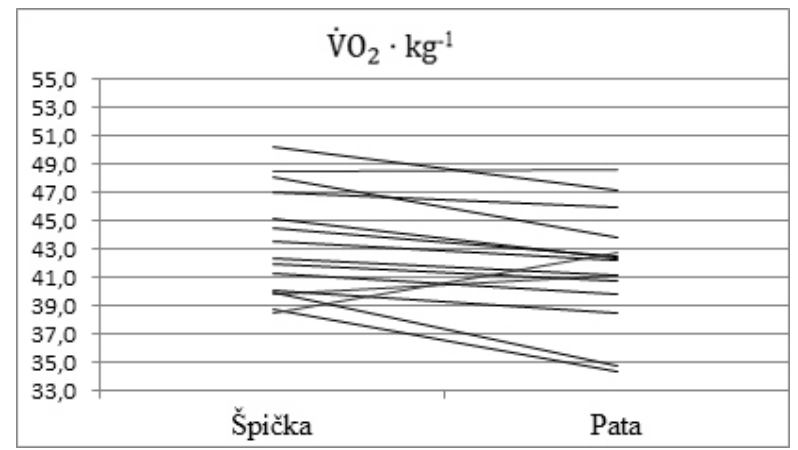

Obr. 3: Graf $\mathrm{VO}_{2} \cdot \mathrm{kg}_{-1}$ u $15 \mathrm{TO}$

Jak je tedy možné, že se všichni atleti snaží došlapovat na přední část nohy, a přes zadní část nohy běhají tzv. hobby běžci nebo běžci, kteří nemají takovou výkonnost, aby dokázali běžet po celou dobu přes přední část nohy. Může se do výsledků promítnout fakt, že lidské tělo se energeticky přizpůsobí určitému způsobu běhu a ve svém výzkumu jsme právě narazili na skupinu běžců, kteří běhají většinu času přes zadní část nohy? Ačkoliv se snažíme naučit optimálnímu běžeckému kroku, tak každý běžec má svůj individuální běžecký styl, který je pro něho typický a vychází jak z genetických předpokladů (výška postavy, tvar chodidla, délka a tvar končetin), tak i ze způsobu běhu, kterým běhá po celý život. Blaise, W., et al. (2012) pojednávají o zjištěné menší síle působící na nohu, hlezno a kyčel při běhu s došlapem na přední část nohy. Je možné, že i naše výsledky vysvětlují, že tyto menší síly působí, protože hlezno s lýtkovými svaly fungují jako tlumič, a to je energeticky náročné. Naše výsledky podporují zjištění Gruber et al. (2013), že ekonomicky př́znivější dopad na špičku je až při běhu ve vyšší rychlosti 14,4 km.h-1 . Avšak v našich podmínkách se vyšší rychlost neosvědčila. V pilotní studii z roku 2011 jsme použili rychlost $14 \mathrm{~km} \cdot \mathrm{h}^{-1}$, ale naše výsledky byly zkreslené právě vysokou rychlostí běhu. Ve své studii jsme se zaměřili na skupinu amatérských běžců. Námi sledovaní běžci nevykazují takovou výkonnost, aby dokázali po celou dobu testu běžet rychlostí $14 \mathrm{~km} \cdot \mathrm{h}^{-1}$. Všechny měřené hodnoty se zvyšovaly s časem a nastávající únavou u běžců. Při rychlosti $14 \mathrm{~km} \cdot \mathrm{h}^{-1}$ jsme u sledované skupiny běžců nedosáhli rovnovážného stavu. Proto jsme snížili běžeckou rychlost. Do jisté míry se naše testovací rychlost $12 \mathrm{~km} \cdot \mathrm{h}^{-1}$ shoduje se střední rychlostí Gruber et al. (2013). Studie Gruber et al. a naše studie probíhala téměř souběžně. Gruber et al. publikuje výsledky v roce 2013. Naše měření probíhalo od roku 2011, kdy byla provedena pilotní studie, a následně v roce 2012 probíhalo měření probandů.

$\mathrm{Na}$ výsledku v závodě se podílí určitě více faktorů, než je jen dobrá ekonomika běhu. Jedním z důležitých 
faktorů může být biomechanika. Domnívám se, že zde může dojít ke konfliktu s ekonomikou běhu, kdy při běhu přes zadní část nohy může být doba kontaktu chodidla s podložkou natolik dlouhá, že běh přes přední část nohy bude z biomechanického hlediska rychlejší, i když z pohledu aerometabolických ukazatelů se bude jednat o opak.

Výzkum byl v roce 2011 podpořen projektem specifického výzkumu FSpS MU č.0058/2011

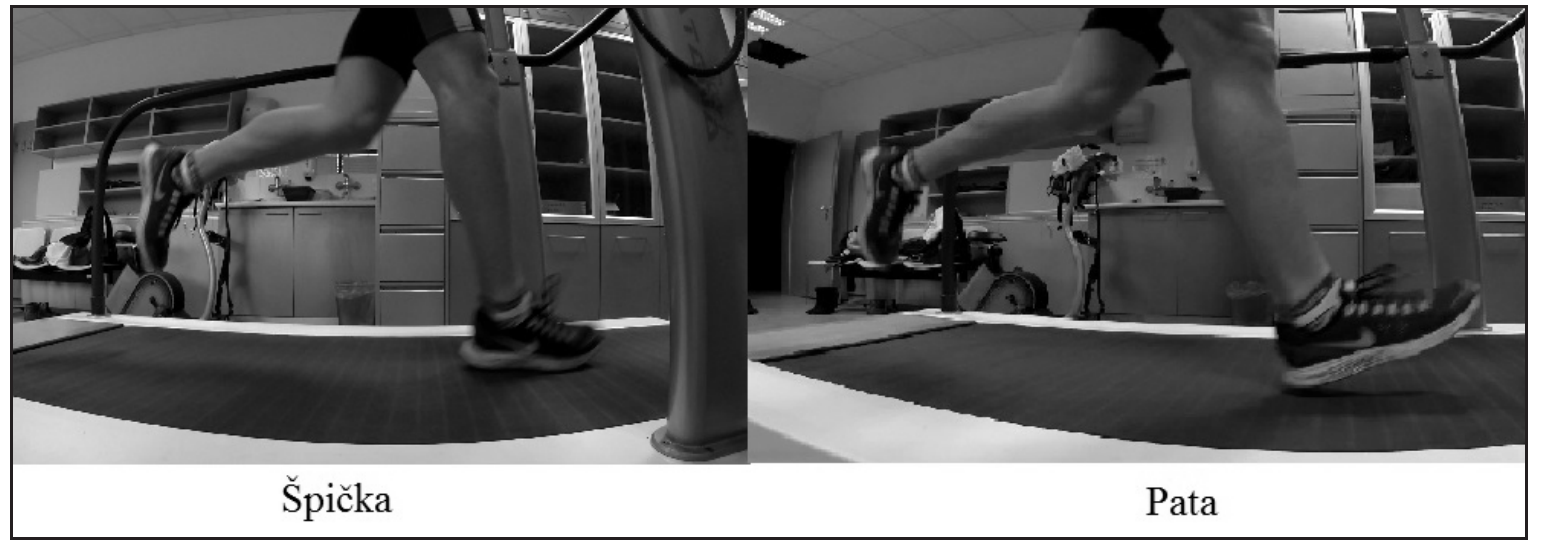

Obr. 4: Porovnání dopadu na špičku a patu ze záznamu kamery

\section{ZÁVĚR}

Statisticky významný rozdíl při běhu s došlapem na přední část nohy a na zadní část nohy byl u minutového př́ijmu kyslíku. Při technice běhu přes přední část nohy byl průměr minutového př́ijmu kyslíku z 15 testovaných osob 3,208 $1 \mathrm{~min}^{-1}$. Při běhu s došlapem na zadní část nohy byla průměrná hodnota minutového př́imu kyslíku o $0,1141 \mathrm{~min}^{-1}$ nižší. Z těchto výsledků bychom mohli usuzovat, že běh s došlapem na zadní část nohy je ekonomicky výhodnější než běh s došlapem na přední část nohy.

Z naměřených 15 běžců nemůžeme jednoznačně říci, zda běh přes zadní část nohy je energeticky méně náročný než běh přes přední část nohy. Rozhodli jsme se pokračovat v testování, abychom dosáhli vyšší míry validity.

\section{LITERATURA:}

Anderson, T. (1996). Biomechanics and running economy. Sports Med 22, 1996, 76-89.

Astorino, T. (2008). Changes in running economy, performance, $V_{2 m a x}$, and injury status in distance runners running during competitive. JEPonline, Vol. 11, N. 6, 2008, ISSN 1097-9751

Ästrand, P. O. (Ed.). (2003). Textbook of work physiology: physiological bases of exercise. Human Kinetics.

Beneke, R. \& Hütler, M. (2005). The effect of training on running economy and performance in recreational athletes. Med Sci Sports Exerc 37, 2005, 1794-1799

Blaise, W., Green, D.S., \& Vurzinger, B. (2012). Changes in lower extremity movement and power absorption during forefoot striking and barefoot running. International Journal of Sports Physical Therapy 7: 525-532

Cavanagh, P.R.; \& Lafortune, M.A. (1980). Ground reaction forces in distance running. J Biomech, 13, 1980, 397-406

Chen, T.C., Nosaka, K., Lin. M.J., Chen, H.L., \& Wu, C.J. (2009). Changes in running economy at different intensities following downhill running. Journal of Sports Sciences. 2009, roč. 27, č. 11, s. 1137-1144. DOI: 10.1080/02640410903062027

Conley, D. L., \& Krahenbuhl, G. S. (1980). Running economy and distance running performance of highly trained athletets. Medicine and Science in Sport and Exercise 12, 357-60

Costill, D. L., \& Winrow, E. (1970) A comparison of two middle-aged ultramarathon runners. Research Quarterly 41, 135-39

Gruber, A.H., Umberger. B.R., Braun, B., \& Hamill. J. (2013). Economy and rate of carbohydrate oxidation during running with rearfoot and forefoot strike patterns. Journal of Applied Physiology, May 16. http://jap. physiology.org/content/early/2013/05/13/japplphysiol.01437.2012.short

Hoffman, J. (2002). Physiological aspects of sports training and performance. Human Kinetics, Champaign 
2002, $343 \mathrm{pp}$

Kyröläinen, H.; Belli, A.; \& Komi, PV. (2001). Biomechanical factors affecting running economy. Medicine and Science 33, 2001, 1330-1337

Noakes, T. (2003). Lore of running. (4th ed., xi, 931 p.) Champaign, Ill.: Human Kinetics.

Nummela, A. (2007). Factor related to top running speed and economy. Int J Sports Med 28, 2007, 655-661

Midgley, A. W., McNaughton, L. R., \& Jones, A. M. (2007). Training to enhance the physiological determinants of long-distance running performance: Can valid recommendations be given to runners and coaches based on current scientific knowledge? Sports Medicine, 37(10), 857-880.

Robbert, M.F. et al. (1992). Mechanical analysis of the landing phase in heel-toe running. J Biomech 25, 1992, 223-234

Saunders, P.U., Pyrne, D.B., Telford, R.D., \& Hawley, J.A. (2004). Factors affecting running economy in trained distance runners. Sports Medicine 34, 2004, 465-485.

Tanner, R., \& Gore, C. (2013). Physiological tests for elite athletes. (2nd ed., xiv, 546 p.) Champaign, Ill.: Human Kinetics.

Zatsiorsky, V. M. (2002) Kinetics of Human Motion. Human Kinetics, Champaign 2002, 653 pp. 